\title{
Child's anxiety preceding the dental appointment: evaluation through a playful tool as a conditioning feature
}

\author{
Ansiedade infantil prévia à consulta odontológica: avaliação mediante instrumento lúdico como \\ condicionamento*
}

Bianca Fiorentin MOURA ${ }^{1}$

José Carlos Pettorossi IMPARATO²

Thaís Manzano PARISOTTO'

Monique DE BENEDETTO'

\section{ABSTRACT}

\section{Objective}

The aim of this study was to evaluate the emotional reactions before and after the application of a child audiovisual book that illustrates the trigger fear and anxiety points in the dental appointment. Moreover, the educational effect of this book as preconditioning to dental care was also verified.

\section{Methods}

The study is a prospective pilot study conducted at the University of Western Santa Catarina with a convenience sample of 20 children aged 4-6 years old, with and without previous dental experience. All these children received the book and they were assessed before and after the presentation by responsible attendants. The projective test FIS (Facial Image Scale) was applied in 2 stages on the same day of assistance. Both tests were applied at the reception waiting room: before the child came into contact with the book in the dental clinic room and after the child came into contact with the playful instrument. Anamnesis and clinical examination were performed in the dental office by the dentist to start or continue the treatment.

\section{Results}

The children were able to answer the projective test with self -analysis. The idealized audiovisual book was successfully constructed and used in the research. The comparison between FIS 1 and FIS 2 made with paired t-test showed significant improvements by comparing the results before the presentation of the playful instrument and after the use of it $(p<0.0001)$, with no differences in childhood anxiety between genders and ages.

Conclusion: The result of the conditioning technique using the book before the dental treatment was highly significant in reducing anxiety.

Indexing terms: Child behavior. Psychology child. Pediatric dentistry.

\section{RESUMO}

\section{Objetivos}

Avaliar as reações emocionais antes e após a aplicação de um livro audiovisual infantil que ilustra os pontos desencadeadores de medo e ansiedade na consulta odontológica. Além disso, verificou-se o efeito educativo desse livro como condicionamento prévio ao atendimento dental.

\section{Métodos}

A pesquisa é um estudo piloto prospectivo conduzido na Universidade Comunitária da Região de Chapecó, com amostra de conveniência de 20 crianças entre 4 a 6 anos de idade, com e sem experiência odontológica anterior. Todas essas crianças receberam o livro e foram avaliadas antes e após a apresentação desse pelos seus responsáveis. Aplicou-se o teste projetivo de FIS (Facial Image Scale), em 2 etapas no mesmo dia do atendimento. Os dois testes foram aplicados na recepção: antes da criança entrar em contato com o livro na sala anexa à clínica odontológica e após a criança entrar em contato com o instrumento lúdico. Foi realizada a anamnese e exame clínico no consultório odontológico pela odontopediatra para iniciar ou dar continuidade ao tratamento.

\section{Resultados}

As crianças foram capazes de responder o teste projetivo com auto-análise. O livro audiovisual idealizado foi construído com sucesso e utilizado na pesquisa. A comparação entre FIS 1 e FIS 2 feito com teste-t pareado apresentou melhoras significativas comparando-se o resultado antes da apresentação do instrumento lúdico e após o uso do instrumento $(p<0,0001)$, sendo que não houve diferença na ansiedade infantil entre os gêneros e as idades.

Conclusão: O resultado da técnica de condicionamento utilizando o livro, antes do atendimento odontológico, foi altamente significativo na redução da ansiedade.

Termos de indexação: Comportamento infantil. Psicologia da criança. Odontopediatria.

\footnotetext{
"Artigo baseado na dissertação intitulada "Avaliação da ansiedade na odontopediatria mediante instrumento lúdico como condicionamento". Faculdade São Leopoldo Mandic; 2014. 135 páginas.

${ }^{1}$ Faculdade São Leopoldo Mandic, Curso de Odontologia, Programa de Pós-Graduação em Odontopediatria. Rua José Rocha Junqueira, 13, Swift, 13045-755, Campinas, SP, Brasil. Correspondência para / Correspondence to: BF MOURA. E-mail: <bifmoura@gmail.com>

${ }^{2}$ Universidade de São Paulo, Faculdade de Odontologia. São Paulo, SP, Brasil.
} 


\section{INTRODUCTION}

Fear of the dentist and the behavioral effects of dental treatment have not been recent research topics and they have been referred to in the literature since $1891^{1}$

In order to promote a better coexistence between children and health professionals while treatments, there has been an increase of scientific and professional interest in psychological aspects ${ }^{2}$. The study of these issues aims to provide the development of more effective coping strategies to deal with potentially stressful contexts. Each child is unique and experiences life in different ways, therefore creating conditions to overcome difficulties during its development and maturation ${ }^{3}$. The dentist's innate ability in dealing with children is of great importance during the dental visit; however, psychology knowledge becomes crucial for a better relationship between the professional and his patient ${ }^{4}$.

Only an appropriate and correct posture of the professional is not enough, There must be a child's preparation coming from parents/or responsible for the child in order to help him face the new situation, always trying to seek positive tools which will minimize the uncertainty regarding the dental treatment ${ }^{5}$.

Thus, the dental care is based on a threedimensional relationship between parents, child patient and Pediatric Dentist ${ }^{6}$ and new psychological methods and educational tools to assist in this process must be created. As Sandrini's ${ }^{7}$ statements, once the child is in the clinic for treatment, his behavior will depend not only on the dentist and his team skills and handling, but also by a previous preparation by the parents is essential.

According to Moraes et al. ${ }^{8}$ the more vulnerable the individual feels in a given situation, the greater the intensity to achieve success in the query.

The lack of the child's psychological preparation of in the dental care tends to cause failures in the treatment efficiency and makes it impossible to be successful. Those responsible and in charge of intending to prepare children for a dental appointment, do so randomly, instinctively and without a protocol, usually committing simple mistakes, with no intention of harming the treatment, nonetheless with large negative impact on him. These mistakes could be eliminated or reduced if the professional could count on a helpful to in order to help the child's conditioning prior to pediatric dentistry assistance therefore preparing him for the dental practice.

since anxiety is an internal emotional state difficult to be observed, but of great importance in the cognitive process, the self-description of this event in a subjective and individual way, helps the child to supply valuable data, once inaccessible, compared to other more objective techniques ${ }^{9}$. In the present study children age 4-6 years old were submitted to the projective test FIS (Facial Image Scale) Buchman \& Niven ${ }^{10}$ for a self-evaluation.

Although several authors mention in their books the importance of behavior control, so far in the literature it has not been found a scientific research proving the efficacy of a children's literature book as prior conditioning for the dental appointment.

Given the above, the importance in the use of strategies that help to cope with emotional stress in children in the dental appointment in order to provide benefits and dealing with the child as a whole human being, becomes a crucial feature.

\section{METHODS}

This research was approved by the Research Ethics Committee (CEP) of the Faculty of São Leopoldo Mandic Dentistry No 199.146 of the CNS. - Ministry of Health).

This manuscript is a pilot study; the sample size set was 20 children ( 10 boys and 10 girls), preschool aged (4-6 years), social classes and different family structures, with and without dental experience. The book used in the research consists of drawings and text illustrating the data pointed in articles trying to trigger fear and anxiety in the dental appointment. It features interactive elements, page with recommendations to parents and a DVD with the story, allowing the standardization of reading.

All children received the audiovisual playful tool and were evaluated in the reception room, before and after the presentation of this, by their parents/responsible, before the dental appointment ${ }^{11}$. Fl 1, a tool used to assess the degree of anxiety was applied by the dentist in the reception room. In the displayed chart, the child had to select the face that best identified with him at that time. When pointing the finger at the chart (Figure 1), a corresponding code was noted and the child was referred for a clinic attached to the room in the presence of the mother or guardian.

Attached to the clinic room, the parent/guardian and the child listened and handled the story book in the presence of the unseen professional (positioned so as not to be seen) and who made no intervention until the end of the story played in the CD (Figure 1), when the toll was collected. After all this, those involved in the procedures were followed back to the front desk. Before the child and his guardian/parent entered into the dental office, still at the reception, the child answered the projective test (FIS 2).The child again pointed to figure that looked like what 
she felt at the moment and the code was jotted down (Figure 1). At the end of the second test, participants were referred to the dental office, where they had the same assistance sequence (form fulfillment, preventive guidelines and clinical examination).

Data were recorded, tabulated and statistically analyzed: a) cross between anxiety level (FIS 1 and FIS 2) and gender done with chi-square test $(\chi 2)(p<0.05)$;

b) comparing levels of anxiety (FIS 1 and 2 ) and age using analysis of variance (one way ANOVA) ( $<<0.05)$; $c$ ) Comparing FIS 1 and FIS 2 done with paired t-test $(p<0.05)$.

Data were initially analyzed using descriptive statistics (mean, standard deviation and frequency analysis).

Chart 1. FIS Scale Code (Facial Image Scale).

\begin{tabular}{|l|c|}
\hline \multicolumn{1}{c|}{ Code } & Emotional reaction \\
\hline
\end{tabular}

\section{RESULTS}

A boy and a 2 girls were excluded from the sample because they were accompanied by an underageperson.

Despite the anxiety had not played any significant influence concerning age and gender, prior and after to book use, the comparison between FIS 1 and FIS 2 was statistically significant for all ages and both genders ( $p$ $<0.0001$ ) as represented in the graphs (Figures 2 and 3) and Table 1.

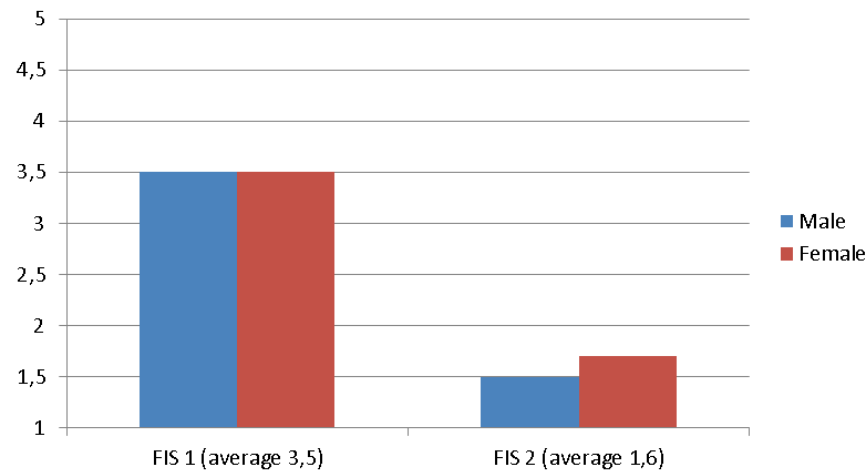

Figure 2. Comparison of the average anxiety concerning the genders (Test FIS1 X FIS2).

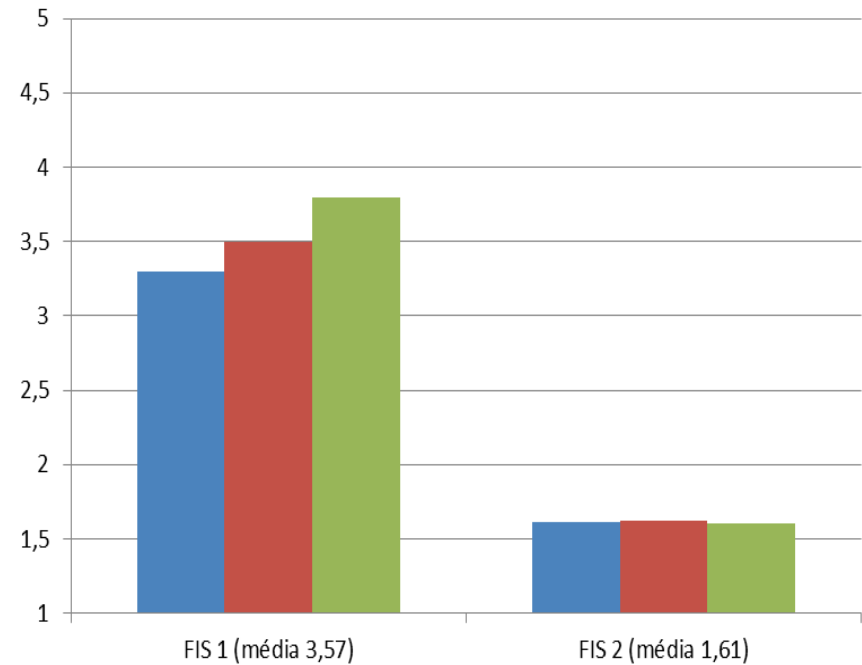

Figure 3.Comparison of average anxiety concerning the ages (Test FIS1 X FIS2). In blue 4 years old, red 5 years old and in green 6 years old children.

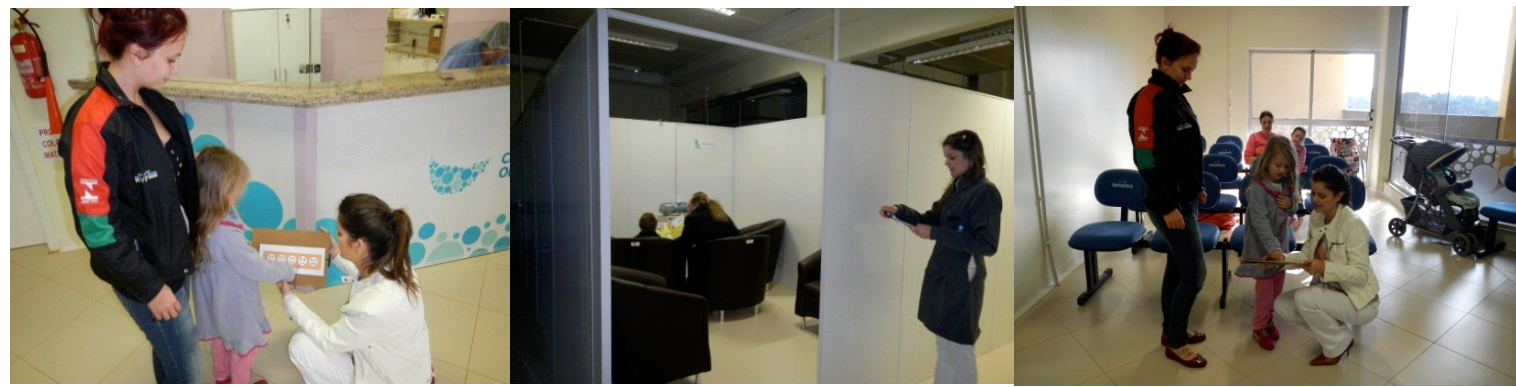

Figure 1. A) Children performed the test 1, chart selection before the playful tool; B) the presentation of the audiobook by the parent/guardian $\mathrm{r}$; C) the children performed the test 2, card selection after playful tool. 
Table 1.Group anxiety distribution (FIS 1 X FIS 2).

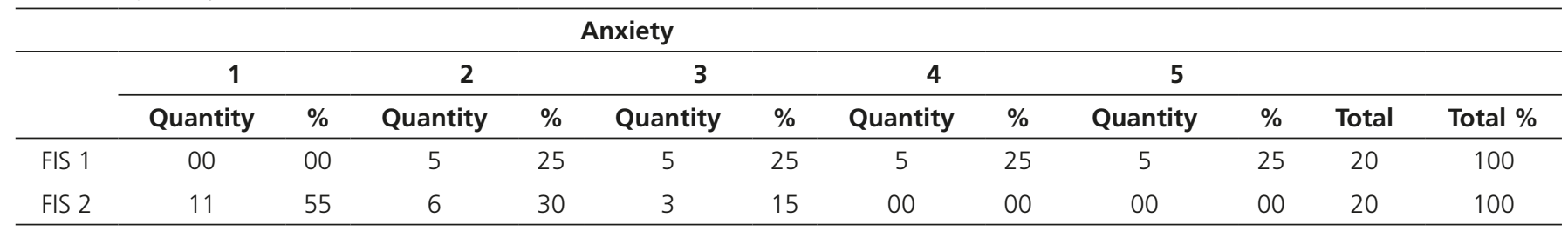

There was a significant decrease in anxiety by applying the book as playful tool as psychological conditioning.

\section{DISCUSSION}

Infant anxiety coming with the dental treatment has been studied by many authors ${ }^{12-14}$. While believing in its complex and multifactorial etiology, the authors claim that anxiety varies quantitatively and qualitatively from child to child, as each individual has its own history, socio-economic and cultural context. However, few recent studies on scientific evidence of helpful techniques to control children's behavior, or even new mechanisms for reducing anxiety have been developed. This research faces this challenge, seeking to achieve results on a new conditioning technique prior to dental care.

Barreto $^{15}$ has stated that the ludic activities are constant features on the human beings' life and although the playful features may vary according to the age and development of the person, it is not limited to children and adolescents, although predominant in these age groups. Chaves $^{16}$ highlights how dentistry and especially Pediatric Dentistry has been concerned in seeking the reduction and removal of anxious behaviors and "disruptive" teaching to these patients, whether adults or children, adjust to dental situations. Lured by these studies and although the work has been proposed to reduce the anxiety of preschool children 4-6 years through the book, the positive results should not be limited only to this age group.

However it must be stated that the authors Koenigsberg \& Johnson ${ }^{17}$ and Rank \& Silva ${ }^{12}$, did not find any statistically significant difference in reducing anxiety emotions among children with or without previous experience at the dentist. Nonetheless this study had as inclusion criterion children with or without previous dental experience, to show that regardless of the situation that the child is, the book can serve as a conditioning tool.

For evaluation of child's dental fear the most common psychometric methods which have been used are projective scales and tests with self-analysis ${ }^{17}$. The projective technique has the ability to provide information which would disclose revealing emotions, if he is prepared in such a way that allows the child to react spontaneously and to show thoughts and feelings of which normally would not talk or express openly in his behavior ${ }^{5,9,18}$.

Ripa \& Barenie ${ }^{19}$ claim that the child reflected in the behavior stressful situations which they experience and so the external behavior is the only way the dentist can truly observe and evaluate. Measure emotional reactions in preschool children are difficult because many concepts used in psychology are not clearly defined, such as anxiety, intelligence and motivation. Therefore, the behavior and childhood anxiety researchers need to use tests and validated scales as resources in order to develop such studies 5 .

There are several scales and tests used in children over 3 years, but for the results of anxiety effect on children's behavior, this research applied the projective test FIS. Buchanan \& Niven ${ }^{6}$ found the effectiveness of the results of the projective test FIS in children 3-18 years. This study found that FIS scale is simple to apply and easy to children understand.

As Frankl et al. ${ }^{20}$, Pfefferle et al. ${ }^{21}$, Fox \& Newton ${ }^{22}$, Arapostathis et al. ${ }^{23}$, showed no differences in the expression of anxiety and dental fear by gender in preschool children, also in our study no results were more significant when compared responses between boys and girls.

Unlike studies of Mink \& Silvestre ${ }^{24}$, Rank \& Silva ${ }^{12}$, Goes et al. ${ }^{25}$, who reported the greater anxiety the younger the age, and the study of Singh et al. ${ }^{26}$ where older children were more fearful, in our study there were no significant results when compared responses between different ages.

As well as the work of the authors $\mathrm{O}^{\prime}$ Callaghan et al. ${ }^{27}$, Fioravante et al. ${ }^{28}$ and Silva et al. ${ }^{29}$, who worked with a sample of 2-5 children, the present study, as a pilot study had a convenient sample of 20 children where the promising results point to a feasible approach, stimulating further research with consistent results.

After applying the playful tool and prior to the child's entry into office, the FIS 2 test was applied, showing reduced anxiety in all evaluated children. The projective method allows the child to reveal their perceptions and 
feelings, demonstrating statistical differences between FIS 1 (before application of the book) and FIS 2 (after application of the book). It has been agreed with the statement of Vieira ${ }^{30}$ and Reis et al. ${ }^{31}$, who pointed to the need to create recreational and pedagogical tools at child appointment, revealing multiple benefits as quality of service is concerned.

The change in anxiety may be associated with age, maturity, personality, intellectual and cognitive ability, temperament, emotions of the day, experience with oral health of the family, socio-economic and cultural context may affect the child's behavior of the child ${ }^{13}$.

In the present study, anxiety showed statistically significant data as compared between tests 1 and 2, namely before and after the application of the book. The emotional state "very sad" reduced by $25 \%$, the "sad" reduced by $25 \%$, the "neutral"/indifferent reduced by $10 \%$. On the other hand, the "happy" increased by $5 \%$ and the "very happy" at 55\%, which showed that there were emotional changes. The conditioning with the children's book was instrumental in the changes thereof confirming what Pedro et al. ${ }^{32}$ pointed out in 2007 when they found that the toy was a great mediator between the professional and the child, expanding their ability to relate to external reality, changing the situation and making it more positive. Playing near the child's professional brings confidence for the child who will undergo an intervention.

When the progress of the 2007 study FIS test was checked, it was observed that the effect of toys in these children reduced infant anxiety, according to the projective test, since playing the child exposes his fantasies, dreams, fears, anxieties and aspirations ${ }^{33}$.

According to Pinkham ${ }^{4}$, the need to change child's negative experiences and expectations when coming for dental treatment is possible as long as she can readapt to a new dentistry. In the process of interaction with the environment, the child gradually develops appropriate psychological structure. This study aims for child's readaptation and confidence in his query to the dentist

\section{REFERENCES}

1. Townend E, Dimigen G, Fung D. A clinical study of child dental anxiety.Behav Res Ther. 2000;38(1):31-46. doi: 10.1016/S00057967(98)00205-8

2. Taylor SE. Health psychology.Nova York: McGrall Hill; 1999.

3. Guedes-Pinto AC, Corrêa MSNP, Giglio EM. Conduta clínica e psicologia em odontologia pediátrica. São Paulo: Santos; 1991. making it an enjoyable and playful experience, interacting with the environment through fantasy and possibly creating a proper psychological framework for this.

The dentist who takes the challenge of taking responsibility for working with children as a patient in pre-school age should keep in mind that the practice of dentistry can not be limited to the prevention or curative treatments, but dealing with the child as a whole human being. Therefore, to enable the expansion of the benefits of care and facilitate the implementation of a high standard dentistry, it is important that professionals seek to work preventively in anxiety and infant emotional tension, in order to avoid the overuse of protective stabilization and pharmacological agents. The task of transforming the patient from captive to cooperator is the master key to improve the relationship of the dentist and patient $t^{2,34}$.

The child patient care must be done and well prepared not only by a dentist, but also by those closely involved with the child. Therefore, this research through a simple and practical conditioning tool, a story book, has brought joy and treatment acceptance thus helping the child feel safe among everyone involved.

\section{CONCLUSION}

There was a significant reduction in childhood anxiety after applying the playful tool (audiovisual book), and there was no difference between ages and genders.

This study seeks to add alternatives to change anxiety and shows that the continued search for viable solutions that help to deal with childhood emotional tension may allow benefits in dental care, dealing with the child as a whole person.

\section{Collaborators}

BF Moura was responsible for all stages of the article. JC Pettorossi IMPARATO, TM PARISOTTO and M DE BENEDETTO participated in the writing of the article.

4. Pinkham JR. Fear of dentistry: a discussion of its usefulness to certain child dental patients. ASDC J Dent Child. 1983;50(2):111-3.

5. Sandrini JC, Bonacin PJ, Christóforo LR.Reações infantis frente ao atendimento odontológico e suas manifestações psíquicas. J Bras Odontopediatr Odontol Bebê.1998;1(3):75-89.

6. Klatchoian DA. O comportamento da criança como elemento chave em odontopediatria. JBP J Bras Odontopediatr Odontol Bebe. 1998;1(4):102-9. 
7. Sandrini JC. Desenvolvimento psicológico da criança e as técnicas de controle comportamental em odontologia pediátrica. JBP J Bras Odontopediatr Odontol Bebe. 1995;4(3):109-18.

8. Moraes ABA, Sanchez KAS, Possobon RF, Costa-Junior AL. Psicologia e odontopediatria: a contribuição da analise funcional do comportamento. Psicol Reflex Crit. 2004;17(1):75-82.

9. Sonnemberg E, Venham L. Human figure drawings as a measure of the child's response to dental visits. ASDC J Dent Child. 1977;44(6):438-42.

10. Buchman $H$, Niven N. Validation of a Facieallamge Scale to assess child dental anxisty. Int J Paediatr Dent. 2002;12(1):4752. doi: 10.1046/j.0960-7439.2001.00322.x

11. Moura BF. A viagem ao consultório do dentista. Chapecó: SG Arte Visual; 2013.

12. Rank RCIC, Silva DRP. Avaliação das reações emocionais em crianças com idade entre 2 a 8 anos, frente a uma sala de espera infantil. FOA. 2002;4(2):47-3.

13. Klingberg G, Broberg AG. Dental fear/anxiety and dental behaviourmanagement problems in children and adolescents: a review of prevalenceand concomitant psychological factors. Int J PaediatrDent. 2007;17(6):391-406. doi: 10.1111/j.1365263X.2007.00872.x

14. Rank RCIC, Carvalho AS, Raggio DP, Cecanho R, Imparato JCP. Reações emocionais infantis após o atendimento odontológico, mediante premiação. RGO, Rev Gaúch Odontol. 2005;53(3):17680 .

15. Barreto RA. O lúdico em odontopediatria: contribuições psicológicas. In: Corrêa MSNP. Sucesso no atendimento odontopediátrico: aspectos psicológicos. São Paulo: Santos; 2002. p. 319-22.

16. Chaves MM. Odontologia social. Porto Alegre: Artes Médicas; 1986.

17. Koenigsberg SR, Johnson R. Child behavior during three dental visits. ASDC J Dent Child. 1975;42(3):197-200.

18. Augras M. A dimensão simbólica. Rio de Janeiro: Fundação Getúlio Vargas; 1967.

19. Ripa LW, Barenie I. Management of dental behavior in children. Littleton: PSG; 1979.

20. Frankl SN, Shiere FR, Fogels HR. Should the parent remain with the child in the dental operatory? J Dent Child.1962;29:150-62.

21. Pfefferle JC, Machen JB, Fields HW, PosnickWR. Child behavior in the dental setting relative to parental presence. Pediatr Dent. 1982;4(4):311-6.

22. Fox C, Newton JT. A controlled trial of the impact of exposure to positive images of dentistry on anticipatory dental fear in children.Community Dent Oral Epidemiol. 2006;34(6):455-9. doi: 10.1111/j.1600-0528.2006.00303.x
23. Arapostathis KN, Coolidge T, Emmanouil D, Kotsanos N. Reliability and validity of the greek version of the children's fear survey schedule-dental subscale. Int J Paediatr Dent. 2008;18:374-9. doi: 10.1111/j.1365-263X.2007.00894.x

24. Vieson RA, Silvestro JR. Psychological tests as predictors of children's operatory behavior. J Dent Child. 1983;50(4):278-82.

25. Góes MPS, Domingues MC, Couto GBL, Barreira AK. Ansiedade, medo e sinais vitais dos pacientes infantis Odontol Clín Cient. 2010;9(1):39-44.

26. Singh KA, Moraes ABA, Bovi-Ambrosano GM. Fear, anxiety and control related to dental treatment. Pesq Odontol Bras. 2000;14(2):131-6. doi: 10.1590/S1517-74912000000200007

27. O'Callaghan P, Allen KD, Powell S, Salama F. The efficacy of noncontingent escape for decreasing children's disruptive behavior during restorative dental treatment journal of applied behavior analysis. J Appl Behav Anal. 2006;39(2):161-71. doi: 10.1901/jaba.2006.79-05

28. Fioravante DP, Soares MRZ, Silveira JM, Zakir NS. Análise funcional da interação profissional-paciente em odontopediatria. Estud Psicol. 2007;24(2):267-77.

29. Silva LPP, Moraes ABA, Rolim GS. Efeitos de procedimento de distração não contingente em tratamento dontopediátrico. Int Psicol. 2008;12(2):179-87.

30. Vieira IMC. O papel dos contos de fadas na construção do imaginário infantil. Rev Criança. 2009;(38) [citado 7 Out 2013]. Disponível em: <http://grupopapeando.wordpress. com/2009/01/27/o-papel-dos-contos-de-fadas-na-construcaodo-imaginario -infantil>.

31. Reis F, Dias MR, Leal I. A consulta no setting odontopediátrico: apercepção subjetiva do medo. Aná Psicol. 2008;2(26):239-50.

32. Pedro ICS, Nascimento LC, Poleti LC, Lima RAG, Mello DF, Luiz FMR. O brincar em sala de espera de um ambulatório infantil na perspectiva de crianças e seus acompanhantes. Rev Latinoam Enfermagem. 2007;15(2):290-297. doi: 10.1590/S010411692007000200015

33. Corrêa MSNP, Maia MES. Abordagem do comportamento para o atendimento odontopediátrico. In: Corrêa MCNP. Odontopediatria na primeira infância. $3^{a}$ ed. São Paulo: Santos; 2010. p.165-77.

34. Natcht ES, Trupkin DP. Ways to improve the service in your pediatric dental office. J ClinPediat Dent 1992;17(1):221-3.

Received on: 1/6/2014 Final version resubmitted on: 27/11/2014 Approved on: 5/3/2015 